\title{
RADIO KOMUNITAS ANAK MUDA
}

\author{
Diana Anggraeni \\ Mahasiswa S3 Komunikasi Pembangunan-Institut Pertanian Bogor \\ Dosen Ilmu Komunikasi Universitas Pancasila \\ e-mail: dachsp@cbn.net.id
}

\begin{abstract}
Abstrak
Tujuan penulisan artikel ini adalah untuk mendeskripsikan dan menjelaskan Radio Komunitas Dapur Remaja (RKDR) sebagai media informasi untuk mengembangkan potensi bagi kalangan anak muda di kawasan Cinangka, Sawangan Depok. Radio komunitas hingga saat ini masih dianggap menjadi media alternatif, untuk menjembatani minimnya informasi kepada masyarakat. radio komunitas disini menjadi sangat penting karena dianggap lebih mengetahui dan memahami persoalan dan isu-isu lokal di sekitarnya. Untuk menjawab rumusan masalah, riset ini menggunakan konsep radio komunitas dan pengembangan masyarakat,. Penelitian ini akan dilakukan dengan metode deskriptif kualitatif dengan melakukan observasi dan wawancara kepada pengelola Radio Komunitas. Hasil penelitian menyatakan bahwa Radio Komunitas Dapur Remaja (RKDR) telah menjalankan fungsinya sebagai media informasi bagi kepentingan warga komunitasnya. Namun informasi tersebut masih terbatas, dikarenakan program-program terkait pengembangan skill yang menjadi fokus pada usaha pengembangan potensi anak muda masih sangat minim. Minimnya kualitas SDM yang memahami persoalan anak muda juga menjadi kendala dalam menyiarkan informasi terkait materi pemberdayaan. Program siaran lebih banyak kepada pemutaran lagu-lagu dan informasi pembangunan yang bersifat umum sehingga tujuan komunitas belum berjalan secara maksimal.
\end{abstract}

Kata Kunci: Radio Komunitas, Media Informasi, Pengembangan Potensi Anak Muda

\section{Pendahuluan}

Pembangunan di Indonesia saat ini mengarah pada partisipasi masyarakat. Masyarakat akan mengetahui kebutuhan informasi pembangunan melalui saluran-saluran komunikasi yang ada. Media komunikasi berupa media komunitas menjadi salah satu alat yang penting dalam hal ini. Media komunitas ditujukan untuk memenuhi kebutuhan informasi yang sesuai dengan kebutuhan masyarakat itu sendiri. Hal ini merujuk pada Undang-undang Dasar 1945 Pasal 28 F yang menyebutkan bahwa "Setiap orang berhak untuk berkomunikasi dan memperoleh informasi untuk mengembangkan pribadi dan lingkungan sosialnya, serta berhak untuk mencari, memperoleh, memiliki, menyimpan, mengolah dan menyampaikan informasi dengan menggunakan segala jenis saluran yang tersedia." Saat ini masyarakat menengah kebawah yang tidak mempunyai pilihan selain mengandalkan pemenuhan informasinya kepada media-media mainstream yang justru menguntungkan para pemilik media, dan informasi yang disampaiakn belum tentu dibutuhkan oleh pendengarnya. Oleh karena itu 
keberadaan media komunitas menjadi sebuah alat yang penting karena dianggap lebih dapat memahami, mengetahui, mengenal kebutuhan dan kebutuhan dari masyarakat disekitarnya.

Media komunitas disini kemudian hadir untuk mengisi kekosongan dan menyuarakan informasi yang terlewatkan di media mainstream. Selain itu media komunitas juga menjadi tempat bagi masyarakat untuk ikut berpartisipasi dalam kegiatan yang membutuhkan keikutsertaan masyarakat sekitar dalam proses aktivitas baik pengembangan pembangunan secara fisik maupun pengembangan yang mengarah kepada peningkatan sumber daya dan potensi masyarakat itu sendiri untuk menjadikan dirinya lebih bermakna.

Sebagai media yang dibangun oleh sekelompok masyarakat atau komunitas, media ini seyogyanya lebih banyak menampilkan informasi yang mendukung kegiatan masyarakat seperti pengembangan dan pemberdayaan masyarakat perdesaan. Baran (2012), menyatakan bahwa media komunitas dianggap sebagai alternatif media untuk menentukan informasi yang dibutuhkan oleh sebuah komunitas tersebut dengan menjalankan fungsi pendidikan, informasi dan hiburan kepada masyarakat disekitarnya serta mampu memberikan manfaat. Media komunitas dianggap sebagai organisasi media di tingkat perdesaan yang memiliki peranan untuk mentransformasikan pesan kepada khalayak dengan ketentuan jarak siaran dan batas geografis (Yuliasari dkk, 2015)

Salah satunya bentuk media komunitas adalah radio komunitas yang memiliki karakteristik dan kemampuan tinggi untuk mendesiminasikan pesan dan informasi pembangunan kepada masyarakat yang terpapar oleh jangkauan siarannya. Radio komunitas menjadi bentuk media penyiaran yang sangat berkembang saat ini. Ditengah kemajuan teknologi saat ini banyak media dituntut untuk menyiarkan pesan dan informasi kepada masyarakat. Tidak hanya bersifat hiburan, namun juga terkait informasi pendidikan, kesehatan ataupun berita pembangunan terutama pembangunan disekitar komunitas tersebut. Radio komunitas berdiri dengan dasar Undang-undang no. 32 tahun 2002 tentang penyiaran. Undang-undang ini kemudian dikuatkan dengan terbitnya Peraturan Pemerintah no. 51 tahun 2005. PP ini masih dianggap kontroversi oleh beberapa kalangan karena dianggap belum berpihak kepada komunitas. Namun sebagai payung hukum PP ini tetap digunakan, sehingga seluruh elemen masyarakat dapat berpartisipasi dalam proses pembangunan melalui media penyiaran seperti radio, televisi ataupun cetak. (Birowo dkk, 2015)

Radio komunitas merupakan media alternatif dalam menyebarkan arus informasi sekaligus menjadi akses interaksi sosial dalam usaha mencapai tujuan komunitas. Penelitian yang dilakukan oleh Effendi dan Makhfudli (2009), menyatakan bahwa radio komunitas adalah wujud media komunitas yang digunakan untuk melawan hegemoni radio swasta dan media massa lainnya yang berfokus kepada keuntungan pemilik media semata. Radio komunitas disini akan berperan untuk memenuhi kebutuhan warga masyarakat sekitar, bukan kepada pemilik modal ataupun pemerintah (Birowo dkk, 2015)

Radio komunitas menurut Sari (2015) adalah media alternatif yang dibentuk dari, untuk dan dikelola oleh sebuah komunitas, sehingga memiliki peran dalam memberikan informasi, pengetahuan dan sebagai media komunikasi sesama anggota komunitas. Dengan demikian kehadiran radio komunitas diharapkan dapat menumbuhkan kesadaran masyarakat akan persoalan yang ada di sekitarnya untuk kemudian mengajak masyarakatnya terlibat dan berpartisipasi dalam penyelesaian masalah tersebut. Masyarakat yang selama ini berperan 
sebagai penerima informasi (pasif) oleh media umum, menjadi peserta aktif dan peduli dalam menentukan program-program yang dianggap penting di komunitasnya. Intinta radio komunitas didirikan untuk melayani kepentingan komunitas itu sendiri (Mukhotib, 2006)

Di Indonesia keberadaan radio komunitas masih sangat sedikit dibandingkan radio komunitas di dunia. Jumlah radio komunitas di Indonesia hanya berjumlah 300. Jumlah ini jauh dibanding dengan Swedia ataupun Denmark. (Ghazali, 2002). Adalah Radio komunitas Dapur Remaja (RKDR) didirikan sejak 29 tahun di wilayah Kelurahan Cinangka, Kecamatan Sawangan. Radio ini berawal sebagai wadah pertukaran informasi antar anggota dan didirikan atas dasar ada rasa keprihatinan tergesernya masyarakat Betawi ke daerah pinggiran yang terpencar-pencar sebagai dampak dari pembangunan di wilayah ibu kota DKI Jakarta. Radio ini bertujuan ingin menyambung komunikasi sesama masyarakat Betawi tersebut. Radio komunitas ini memiliki Izin Prinsip Penyelenggaraan Penyiaran dari Komisi Penyiaran Indonesia nomor 52/RF.03.02/2017 dan Izin Stasiun Radio nomor 01945903 000SU/2020172022 dengan frekwensi 107.8 FM atau sekarang juga disiarkan secara streaming di www.dapurremajafm.com.

Radio komunitas didirikan oleh sebuah komunitas yang bernama Komunitas Dapur Remaja. Komunitas atau disebut dalam istilah lainnya 'community' memiliki arti orang yang hidup dalam suatu tempat dan memiliki kepentingan serta ketertarikan yang serupa (Maryani, 2011). Komunitas terbentuk berdasarkan batas wilayah, kesamaan identitas, minat, kepedulian maupun kepentingan (Sudibyo, 2004).

Komunitas Dapur Remaja pada awal berdirinya hanya sebagai wadah untuk menyambung silaturahmi dengan mengadakan kegiatan-kegiatan pertemuan rutin. Namun pada perkembangan kemudian komunitas ini berusaha memberikan manfaat lebih tidak hanya sebagai tempat berkumpul namun juga bagaimana mampu menciptakan sebuah usaha-usaha pengembangan masyarakat khususnya potensi anak muda yang ada dan sering berkumpul disekitar wilayah Sawangan Depok. Komunitas binaan meliputi 3 hal yaitu Dapur Remaja Greencampbone, Dapur Remaja Networking, dan Dapur Remaja Publishing.

Radio Komunitas Dapur Remaja difungsikan juga sebagai media untuk menyebarkan informasi terkait kegiatan komunitas binaan tersebut. Sebagai wadah pengembangan potensi anak muda, radio komunitas ini berusaha untuk mengadakan kegiatan-kegiatan yang disampaikan sesuai dengan kebutuhan yang merujuk kepada karakteristik dan potensi kearifan lokal dari lingkungan komunitasnya. Hal ini merujuk pada pemahaman yang disampaikan oleh Wallace (1996) bahwa, 'pengembangan masyarakat saat ini harus memuat gagasan mengenai kelangsungan ekologis, keadilan sosial dan hak asasi manusia, dengan menghubungkan kearifan lokal dan globalisasi (Ife dan Teroriero, 2016). Dari proses pengembangan anak muda yang dilakukan melalui radio komunitas ini, kemudian diharapkan mampu memberdayakan potensi dari anak muda tersebut menjadi lebih baik dari yang sudah ada. Dari penjabaran diatas maka penulisan artikel ini bertujuan untuk mendeskripsikan dan menjelaskan peran Radio Komunitas Dapur Remaja sebagai media untuk pengembangan potensi anak muda di wilayah Cinangka, Sawangan Depok.

\section{Tinjauan Pustaka}

\section{A. Radio komunitas}


Radio merupakan media elektronik yang bisa dirasakan melalui indera pendengaran. Modal utama dari radio adalah saluran dan suara yang disampaikan kepada khalayaknya untuk mendengarkan siaran seperti musik, informasi, peristiwa, diskusi ataupun materi-materi acara yang diplih oleh radio tersebut. (Masduki, 2005). Fungsi Radio antara lain adalah untuk menyebarkan informasi, menghibur, membujuk serta mendidik pendengarnya melalui kekuatan suara. Radio diperkenalkan oleh Marchese Guglielmo Marconi pada tahun 1894 dan mengalami perkembangan yang sangat pesat pada tahun 1930 ketika Edwin Howard Amstrong mengembangkan frekwensi modulasi (FM) yang memiliki keunggulan suara lebih jernih serta kualitas yang mampu meminimalisir gangguan dan digunakan pada radio modern hingga saat ini. (Morissan, 2008).

Radio mainstream saat ini dianggap hanya menguntungkan pemilik media dan tidak mampu menyediakan informasi bagi seluruh lapisan masyarakat. Ketidakmampuan ini kemudian membuat masyarakat menengah kebawa membuat sebuah media yang bersifat lokal agar mampu menyuarakan aspirasi masyarakat lokal dengan mendirikan radio komunitas (Caerowati dkk. 2013). Radio komunitas menjadi media yang dianggap mampu sebagai wadah untuk mewujudkan kebebasan berekspresi, mampu membantu, mengerti dan menyelesaikan masalah di lingkungannya serta memberikan informasi-informasi yang dibutuhkan oleh masyarakatnya, juga melibatkan warga masyarakat untuk ikut serta berpartisipasi dalam mengembangan program-program radio tersebut.

Pembentukan radio komunitas di Indonesia mengacu kepada Nomor 32 tahun 2002 bagian keenam pasal 21-24 Tentang Penyiaran dengan istilah Lembaga Radio Komunitas (LPK) dengan ciri memiliki Badan hukum Indonesia, didirikan oleh sebuah komunitas tertentu (sesuai dengan latar belakang pembentukannya). (Oramahi, 2012). LPK bersifat independen, memiliki daya jangkau terbatas. LPK sendiri di bangun untuk memenuhi kepentingan komunitasnya. Sehingga dapat dikatakan bahwa pendanaannya juga berasal dari komunitas itu sendiri. Ciri lainnya yaitu tidak mencari keuntungan semata, memiliki usahausaha untuk mendidik dan memajukan komunitasnya serta tidak berorientasi politik. Frekuensi LPK diatur oleh Negara pada 107,7 MHz hingga 107,9 MHz dan radius siaran yang dibatasi maksimum 2,5 km dari lokasi pemancar atau dengan Effective Radiated Power (ERP) maksimum 50 (lima puluh) watt. (Kridasaksana dkk, 2017)

Radio komunitas dianggap sebagai media yang bisa memenuhi kebutuhan informasi untuk kelompok-kelompok marjinal. Menurut AMARC (Association Mondiale Des Radiodiffuseurs Communautaires - www.amarc.org) atau Organisasi Pegiat Radio Komunitas Seluruh Dunia, menyatakan bahwa radio komunitas memiliki ciri:

(1) Tidak mencari keuntungan,

(2) Kepemilikan dan kontrol ada pada komunitas, dan

(3) Partisipasi komunitas.

Committee on Media and Culture European Union 2004-2009 mendefinisikannya media komunitas sebagai: "Community Media (CM) are addressed to specific target groups. They have a clearly-defined task, which is carried out in line with their content. Sosial benefit for a community is a primary concern". (Effendy, 2013).

Suvillan (1994) menyatakan bahwa, 'Community media may also sometimes be classed as alternatives in that they frequently represent groups who feel that the viewpoints and 
concerns are not sufficiently represent within existing local and national media'. Sebagai salah satu media komunitas, radio dianggap sebagai media alternatif untuk mewakili masyarakat yang tidak terjangkau media yang ada atau mungkin tidak familiar dengan budaya popular dan modernitas. Masyarakat disini dianggap tidak memiliki daya beli dan tidak menjadi fokus bagi media mainstream.

Bentuk organisasi radio komunitas merupakan organisasi yang terbentuk melalui komunitas atau perkumpulan yang memiliki tujuan yang sama. Sebagai badan yang berbentuk organisasi pada umumnya, maka radio mempunyai struktur organisasi. Seperti umumnya radio komunitas lainnya, radio ini memiliki struktur organisasi yang sederhana seperti Dewan Pembina, Direktur (pengelola) yang dibantu dengan sekretaris dan bendahara dan dibantu oleh koordinator teknis, repoter dan penyiar. Setiap bagian memiliki fungsi dan peran masingmasing. Dewan Pembina umumnya adalah dari tokoh masyarakat setempat yang memiliki visi, misi yang sama terhadap pengelolaan radio komunitas. Pengelola atau direktur adalah orang yang memiliki kemampuan untuk membuat perencanaan dan pengendalian terhadap manajemen. Sementara itu pada pada level staf adalah mereka yang menjalankan kegiatan sehari-hari sesuai dengan keahlian masing-masing (Manullang, 2008). Darmanto et all (2015), menyatakan bahwa manajemen radio komunitas adalah penyelenggaraan siaran radio yang terencana, terorganisasi, dapat dilaksanakan dan diawasi sesuai tujuan yang sudah ditetapkan yang dilakukan oleh warga komunitas.

Selain manajemen, radio komunitas dalam mengoperasionalisasikan radionya harus

juga melakukan aktivitasnya secara benar terkait program siaran, bagaimana memproduksi program siaran sendiri, mampu menyediakan prasanara dan sarana, pengelolaan alat-alat siaran, pengelolaan sumber daya manusia serta monitoring dan evaluasi. Tentunya daalm proses perencanaan dan pembuatannya akan melibatkan masukan, input dan kesepakatan antara manajemen dan anggota komunitas. Dalam hal ini, manajemen Radio Komunitas Dapur Remaja melibatkan anggota komunitas dalam keseluruhan kegiatan yang dilakukan secara berkesinambungan termasuk pembiayaannya.

\section{B. Pengembangan masyarakat}

Pengembangan masyarakat berasal dari dua kata yaitu Pengembangan dan Masyarakat. Pengembangan berarti kegiatan untuk meningkatkan kualitas manusia. Sementara itu masyarakat merujuk kepada sekelompok orang yang memiliki kepentingan bersama, budaya dan lembaga yang khas dan memiliki tujuan yang bersama. Didalam masyarakat terdapat kelompok-kelompok kecil masyarakat yang dikenal dengan istilah komunitas. Komunitas dimaknai sebagai individu-individu yang memiliki maksud, kepercayaan, sumber daya, preferensi, kebutuhan, risiko, kegemaran dan sejumlah kondisi lain yang serupa atau sekelompok orang dengan identitas bersama (tempat, minat dan tujuan). Komunitas adalah sebuah unit atau kesatuan sosial yang terorganisasikan dalam kelompok-kelompok dengan kepentingan bersama. Soemardjan (1962) yang dikutip oleh Nasdian (2014) menyatakan komunitas merupakan sebuah wilayah kehidupan sosial yang ditandai dengan derajat hubungan sosial tertentu yang meliputi lokalitas dan perasaan semasyarakat setempat.

Menurut AMA (1993), Pengembangan masyarakat merupakan sebuah usaha yang dilakukan untuk meningkatkan potensi dan kualitas hidupnya serta mampu memperbesar 
pengaruhnya terhadap proses-proses yang mempengaruhi kehidupannya. Pengembangan disini diarahkan pada potensi dasar yang ada yang dimiliki seseorang baik fisik maupun mental dan memiliki kemungkinan untuk dikembangkan. (Majdi, 2007). Pengembangan masyarakat dilakukan mulai dari proses membantu masyarakat menganalisa masalah mereka, untuk melaksanakan sebagai ukuran besar otonomi yang mungkin dan layak, dan untuk mempromosikan identifikasi yang lebih besar dari warga negara individu dan individu organisasi dengan masyarakat secara keseluruhan (Warren, 1978).

Sanders (1958) mengatakan bahwa pengembangan masyarakat adalah sebuah proses yang bergerak maju dari satu tahap ke tahap yang lain yang mempunyai, tujuan antara lain: menimbulkan kepercayaan kepada diri sendiri, menimbulkan rasa bangga, semangat, dan gairah kerja, kemudian mampu meningkatkan dinamika untuk membangun dan meningkatkan kesejahteraan masyarakat. (Nasdian, 2014). Pengembangan disini dipahami sebagai sebuah usaha untuk mengembangkan minat dan kreativitas.

Unsur - unsur pengembangan masyarakat antara lain (Effendi dan Makhfudli, 2009):

a. Program terencana yang berfokus kepada kebutuhan secara menyeluruh (total needs) dari masyarakat.

b. Mendorong swadaya/pemberdayaan masyarakat (empowerment).

c. Adanya bantuan teknis dari pemerintah maupun badan-badan swasta atau organisasiorganisasi sukarela, yang meliputi tenaga personil, peralatan, bahan ataupun dana melalui kemitraan.

d. Mempersatukan berbagai spesialisasi seperti pertanian, peternakan, kesehatan masyarakat, pendidikan, kesejahteraan keluarga, kewanitaan, kepemudaan, untuk membantu masyarakat.

Dari penjelasan diatas dapat disimpulkan bahwa pengembangan masyarakat merupakan kegiatan atau usaha (pelatihan, pendidikan ataupun pemberdayaan) yang ditujukan kepada masyarakat ataupun komunitas menuju ke arah yang lebih baik untuk pemberdayaan dirinya, sehingga mampu berperan dan berpartisipasi dalam kegiatan pembangunan (fisik maupun mental) di sekitarnya. Hakikat pengembangan masyarakat itu sendiri adalah untuk meningkatkan kesejahteraan manusia atau masyarakat (Effendy, 1998).

\section{Metodologi}

Makalah ini menggunakan pendekatan kualitatif deskriptif yang menitik beratkan kepada wawancara, untuk melihat dan menjelaskan perilaku dan sikap-sikap tertentu dari objek penelitian yang dilakukan (Cresswell, 2015). Dengan menggunakan pendekatan ini maka akan dapat dijelaskan perilaku dan sikap dari Radio Komunitas Dapur Remaja dalam mengoperasionalkan radio sebagai media informasi dari komunitas yang binanya.

Terkait topik dalam penelitian ini, peneliti mendapatkan informasi melalui data primer berupa wawancara secara mendalam (in-depth interview) dengan penanggung jawab operasional Radio Komunitas Dapur Remaja yaitu Adi Ones, untuk mendapatkan gambaran tentang RKDR terkait latar belakang pendirian, tujuan, manajemen, pembiayaan, program, evaluasi dan lain sebagainya yang telah dilakukan selama ini. Data sekunder didapatkan dari beberapa berita baik cetak maupun online kemudian juga dengan melakukan studi literatur 
dari beberapa buku dan jurnal. Untuk melengkapi data diatas, peneliti juga melakukan observasi dengan mengunjungi Radio Komunitas Dapur Remaja.

Setelah semua data dikumpulkan dan disatukan, maka akan dilakukan analisa hasil temuan lapangan dengan konsep yang ada untuk mendeskripsikan apakah Radio Komunitas Dapur Remaja sudah berperan sebagai media informasi bagi pengembangan potensi anak muda khususnya di kawasan Cinangka, Sawangan Depok.

\section{Hasil Penelitian}

Komunitas Dapur Remaja didirikan atas berdasarkan Badan Hukum KumHam Perkumpulan Komunitas Dapur Remaja Nomer: AHU-0009240.AH.01.07.Tahun 2017. Sementara itu Radio Komunitas Dapur Remaja (RKDR) mendapatkan Ijin prinsip Penyelenggaraan Penyiatan (IPP) No. 267 dan Izin Stasiun Radio (ISR) No. 01945903000SU/2020172022 pada tahun 2017. Komunitas dan Radio ini sendiri berdiri sejak 29 tahun yang lalu. Visi RKDR adalah 'Melayani kebutuhan informasi warga Komunitas'. Sementara itu misinya adalah 'Sebagai media Alternatif yang mengisi kesenjangan berita media konvensional'. Tujuan berdirinya RKDR ini oleh pendirinya adalah sebagai berikut:

a. Melayani kebutuhan informasi dan silaturahmi warga komunitas

b. Sebagai media alternatif yang mengisi kesenjangan berita media konvensional

c. Mengambil peran untuk mengisi content seperti: pengembangan usaha dan ketrampilan lokal, transparansi anggaran pemerintahan lokal (dalam hal ini Pemerintah Kota Depok), isu-isu pembangunan lokal dan informasi kegiatan sosial seperti penanganan bencana di wilayah Depok.

Tujuan ini meneruskan cita-cita pendiri komunitas yang menginginkan adanya peningkatan kesadaran masyarakat di Depok dan sekitarnya untuk berpartisipasi secara aktif dalam pembangunan di wilayah Depok. Radio ini bersiar di frekwensi 107.8 FM atau dapat diakses secara streaming di www.dapurremajafm.com. RKDR membidik masyarakat yang berlatarbelakang budaya Betawi. Hal ini tercermin dari nama-nama program siaran, gaya komunikasi yang dilakukan yang merupakan perpaduan bahasa Indonesia dan Betawi, musikmusik lebih banyak bergenre dangdut serta memiliki waktu siaran dari jam 05.00 hingga jam 02.00 Wib.

Komunitas ini mempunyai 3 bidang kegiatan yang dibina yaitu DR Greencampbone yang memiliki kegiatan dibidang sosial dan lingkungan hidup seperti bersih sungai, mendaki gunung, penghijauan dan penanaman pohon, dan pelatihan-pelatihan lainnya. Kemudian DR Networking yang menekankan pada pelatihan pembuatan website, jaringan interkoneksi, IT, design grafis dan aplikasi. Dan terakhir DR Publishing yang memfokuskan pada kegiatan pelatihan membuat sablon, design untuk kaos, seni lukis, event organizer, wayang golek Depok yang terbuat dari batok kelapa, ondel-ondel yang ditujukan untuk melestarikan dan mempertahankan budaya Betawi di Depok.

Program materi penyiaran komunitas yang disiarkan melalui RKDR dari hasil observasi peneliti juga belum banyak materi pelatihan yang disiarkan. Informasi yang disiarkan secara on air masih sebatas penyebaran dan pesan informasi akan diadakannya kegiatan atau event yang dilakukan oleh komunitas saja, itupun hanya 1 atau 2 kali dalam sebulan. Program siaran terkait pelatihan ataupun cara-cara meningkatkan keahlian yang 
diberikan di kegiatan binaan masih belum ada. Jadi kegiatan pelatihan lebih pada kegiatan off air.

\section{Diskusi}

Media komunitas di Indonesia masih relatif baru. Keberadaannya mulai berkembang mulai awal tahun 2000-an, walaupun wacana pembentukan sudah dimulai sejak adanya advokasi untuk merevisi UU no. 24 tahun 1997 tentang penyiaran (Hasandinata, 2014). Saat ini jumlahnya juga masih sedikit dibanding dengan Negara lain. Ghazali (2002) menyatakan bahwa Swedia memiliki sekitar 2.000 radio komunitas, Denmark 300 radio komunitas sementara itu Indonesia baru ada sekitar 300 radio komunitas. Radio komunitas dapur remaja (RKDR) sendiri sudah berdiri sejak 29 tahun yang lalu. Mulai mengurus perijinan pada tahun 2004 dan baru mendapatkan ijin penyiaran di tahun 2017. Pendirian komunitas dan radio ini diawali dengan seorang inisiator yaitu Alm. Asam Leo untuk mengumpulkan kembali masyarakat Betawi yang 'tergusur' dari wilayah ibu kota dan pindah ke daerah pinggiran terutama Depok dan Tangerang. Awalnya komunitas ini mengadakan pertemuan yang diadakan secara rutin setiap beberap bulan, namun pada perkembangannya kemudian, pengelola komunitas mulai memikirkan bagaimana memberdayakan anggotanya untuk menjadi lebih berkualitas daripada hanya sekedar berkumpul.

Sebagai media komunitas yang mempunyai tujuan untuk mengembangkan potensi anak muda di wilayah Sawangan depok, RKDR berperan dalam menyebarkan informasi terkait pelatihan-pelatihan yang diadakan di komunitas tersebut. Penyampaian informasi biasanya dilakukan 2 minggu atau 1 bulan sebelumnya, tergantung apakah kegiatan tersebut melibatkan banyak atau sedikit peserta.

Karakteristik komunitas dapur remaja adalah masyarakat umum dan berlatarbelakang budaya Betawi khususnya dengan usia khalayak berkisar berumur 20-50 tahun/ 70\% dari total pendengar. Hal ini dituangkan dalam tagline RKDR yaitu 'Aulanya Anak Muda, Dewasa yang Berhati Remaja'. Hal ini menunjukan bahwa segmen pendengar RKDR adalah seluruh masyarakat yang memiliki kesamaan minat tentunya dalam pengembangan masyarakat. Anak muda sendiri dicerminkan sebagai sosok yang aktif, berprestasi, kreatif, inovatif dan memiliki jiwa usaha untuk mengembangkan hidupnya.

Program radio, tentunya di sesuaikan dengan program komunitas. Seperti diketahui bahwa program komunitas adalah mengembangkan potensi anak muda. Program ini diambil awalnya dengan keprihatinan pengelola komunitas kepada anak muda yang menganggur, nongkrong tidak tahu apa yang harus dikerjakan, sehingga timbul inisiatif untuk membuat kegiatan yang bermanfaat. Dari kumpul-kumpul tersebut, kemudian dibuatlah program yang bisa merangkul berbagai kegiatan sesuai dengan kebutuhan anak muda tersebut, sehingga muncullah program-program seperti bersih lingkungan, pelatihan sablon, mekanik dan lain sebagainya. Perencanaan program dilakukan disesuaikan dengan input atau masukan dari warga komunitas melalui mekanisme diskusi rutin yang diadakan setiap 3 bulan sekali. Focus group discussion (FGD) terkadang dilakukan jika ada hal-hal lain yang dianggap penting untuk dicarikan solusi terkait permasalahan yang ada dalam komunitas tersebut. Jika ada input yang dianggap sangat penting untuk dilakukan, biasanya manajemen komunitas maupun radio 
bisa saja mengadakan kegiatan ditengah-tengah kegiatan yang sudah direncanakan sebelumnya.

Bentuk kegiatan yang sudah dilakukan yang bersifat rutin adalah bersih sungai pesanggrahan, pelatihan memasak, sementara pelatihan lainnya yang pernah dilakukan adalah pelatihan public speaking, pelatihan first aid, manajemen radio, penyiar dan sebagainya. Peserta dari pelatihan yang diadakan oleh komunitas meliputi masyarakat umum yang memang memiliki kesamaan minat dengan kegiatan yang diadakan, kalangan siswa mulai dari SMP hingga Universitas. Peran radio komunitas disini lebih kepada media untuk menginformasikan atau mempromosikan kegiatan tersebut, sehingga pendengar radio dapat mengetahui kegiatan apa saja yang diadakan oleh komunitas dapur remaja. Hal ini dapat menjelaskan bahwa RKDR sebagai media warga yang bersifat lokal telah sesuai dengan pendiriannya adalah menjadi media informasi kepada anggota komunitasnya, mampu menyuarakan aspirasi masyarakat lokal dengan mendirikan radio komunitas (Caerowati dkk, 2013), serta mewujudkan kebebasan berekspresi, memberikan dan memenuhi kebutuhan informasi-informasi sehingga warga komunitas dan masyarakat umum dapat ikut serta berpartisipasi dalam kegiatan-kegiatan yang diadakan.

Dalam hal pembiayaan radio komunitas umumnya mendapatkan dari sumbangan warga komunitas ataupun iklan. Demikian juga dengan RKDR yang mengandalkan sumbangan dari anggotanya, pemasukan dari iklan layanan masyarakat, dan dari hasil kegiatan yang dilakukan.

Radio komunitas bekerja untuk memenuhi kebutuhan informasi masyarakatnya. Disini masyarakat yang merupakan anggota komunitas dapat berpartisipasi secara luar mulai dari tahap perencanaan, penyelenggaraan, pembiayan hingga sampai evaluasi.

Pada tahap perencanaan, yang dilakukan oleh RKDR adalah membuat program sesuai dengan visi misi yang sudah ditetapkan. Hal ini termasuk didalamnya berupa jenis program siaran, waktu siaran, sumber daya manusia yang ikut mengelola radio komunitas. Perekrutan SDM dilakukan secara rutin. Semua anggota dapat mengajukan diri termasuk menjadi penyiar untuk berperan memajukan komunitas. Namun kendala yang dihadapi dalam permasalahan SDM ini adalah belum adanya honor yang diberikan kepada penyiar. Penyiar yang ada sebagian besar adalah anggota komunitas yang mempunyai passion dalam dunia penyiaran.

Yuliasari (2015) menyatakan bahwa tantangan paling besar bagi radio komunitas yang memiliki segmen pendengar komunitas terletak pada kemampuan untuk mengemas informasi sesuai kebutuhan warga. Penyiar yang tergabung di RKDR bebas menentukan tema siaran yang dibawakannya dengan menerapkan metode partisipatif dapat digunakan untuk memberikan kesempatan bagi pendengar untuk melakukan dialog interaktif. Namun hal ini menyebabkan materi siaran menjadi umum dan kurang memberikan informasi terkait pengembangan yang ingin dilakukan. Namun dari model komunikasi tersebut dapat pula digali kebutuhan informasi tentang isu-isu lokal dan apa yang dibutuhkan, permasalahan komunitas yang dihadapi, serta masukan dan harapan lainnya yang mungkin belum dipikirkan oleh manajemen komunitas maupun radio.

Program siaran di RKDR dinamakan dengan segala sesuatu yang berhubungan dengan dapur hal ini sesuai dengan awal pendirian RKDR yang disiarkan dari dapur milik pendirinya. Saat ini pengelolaan dan manajemen RKDR dipegang oleh generasi kedua yang berusaha 
untuk tetap menjalankan aktivitas komunitasnya. Radio komunitas dibentuk dari, oleh dan untuk komunitas, karenanya radio komunitas dituntut untuk mempunyai positioning sesuai dengan identitas lokalnya dengan merangkul anggota komunitas utnuk berpartisipasi menjadi bagian dalam penyiaran yang dilakukan. Manajemen seyogyanya menjadikan Radio komunitas menjadi media yang mampu menampung aspirasi dan menjadi wadah dialog antar berbagai unsur dalam masyarakat khususnya anak muda sesuai dengan target sasaran komunitas dan bertindak sebagai mediator untuk menjembatani proses pembangunan yang dilakukan oleh pemerintah dengan masyarakatnya. Hal ini sangat penting mengingat pelaku pembangunan sesungguhnya adalah masyarakat yang didalamnya terdiri dari berbagai komunitas. Radio Komunitas Dapur Remaja sebagai media komunitas sendiri kedepannya dituntut untuk lebih berperan dalam proses pembentukkan dan menguatkan potensi lokal.

\section{Kesimpulan}

Dari uraian diatas dapat disimpulkan bahwa hingga saat ini radio komunitas di Indonesia masih merupakan media penyiaran alternatif, yang pembentukannya dibuat dari, oleh dan untuk warga komunitas itu sendiri. Radio komunitas disini berfungsi untuk menjangkau masyarakat yang spesifik yang bukan merupakan segmen dari radio mainstream. Oleh karena berasal dari warga komunitas itu sendiri, maka program yang disiarkan menjadi lebih khusus yang disesuaikan dengan karakteristik komunitas dan sesuai dengan kebutuhan masyarakat tersebut.

Radio komunitas dapur remaja di kawasan Cinangka, Sawangan Depok sejak awal pendiriannya telah mengambil posisi untuk usaha pengembangan yang melibatkan patisipasi anak muda di wilayahnya dengan mengadakan pelatihan-pelatihan yang berhubungan dengan usaha pengembangan diri, wirausaha, kegiatan sosial dan lingkungan hidup

Program yang disiarkan menyasar segmen anak muda yang sebagian besar dibawakan dalam balutan budaya Betawi. Peran Radio Komunitas Dapur Remaja disini adalah sebagai media informasi yang mendukung kegiatan dari komunitas. Walaupun belum terlalu banyak pesan dan informasi terkait yang disampaikan, namun RKDR telah menjadi media untuk menyebarkan kegiatan komunitas secara on air.

Dalam menjalankan siarannya, RKDR masih terkendala dengan masalah pendanaan yang masih mengandalkan kepada sumbangan dari anggota komunitasnya. Iklan layanan Masyarakat belum terlalu banyak dikarenakan jangkauan daya siar yang terbatas. Permasalahan SDM juga ditemui karena tidak banyak penyiar yang memahami permasalahan terkait apa yang dibutuhkan oleh kalangan anak muda, sehingga materi siaran lebih bersifat umum, Namun positioning dari RKDR telah sesuai dengan pengembangan anak muda, hal ini dapat dilihat dari program2 off air dan on air-nya.

\section{Daftar Pustaka}

AMA. (1993). Local Authorities and Community Development: A Strategic Opportunity for the 1990s. London: Association of Metropolitan Authorities.

Baran, Stanley J. (2012). Pengantar Komunikasi Massa: Melek Media dan Budaya. Edisi 5, Jakarta: Erlangga 
Birowo, Mario A., Prakoso, Imam dan Nasir, Akhmad. (2015). Mengapa Radio Komunitas. Yogyakarta: Combine

Caerowati, Dede Lilis., Yuliati Nova., Rochim Mochamad. (2013). Mengusung Masyarakat Madani melalui Radio Komunitas. Jurnal Mimbar. https://ejournal.unisba.ac.id/index.php/mimbar/article/view/399

Creswell, John W. (2015). Research Design. Pendekatan Kualitatif, Kuantitatif dan Mixed. Yogyakarta: Pustaka Pelajar

Darmanto, A., Masduki., Kurniawan, Panca Adi. (2015). Manajemen dan Produksi Radio Komunitas. Yogyakarta: Combine Recource Institution. https://issuu.com/signin?onLogin=\%2Fcombineri\%2Fdocs\%2Febook_manajemen__ _produksi_radio_ko.e-book

Effendy, Nasrul. (1998). Dasar-dasar Keperawatan Kesehatan Masyarakat. Edisi 2. Jakarta:EGC.

Effendy, Rochman. 2013. Peran Radio Komunitas dalam menumbuhkembangkan Civic Community.http://www.academia.edu/10401680/Peran_Radio_Komunitas_dalam_M enumbuhkembangkan_Civic_Community.

Efendi, Ferry dan Makhfudli. (2009). Keperawatan Kesehatan Komunitas: Teori dan Praktik dalam Keperawatan. Jakarta: Salemba Medika.

Ghazali, Effendi, (2002). Penyiaran Alternatif Tapi Mutlak, Sebuah Acuan Tentang Penyiaran Publik dan Komunitas. Jakarta : Jurusan Ilmu Komunikasi FISIP, Universitas Indonesia.

Hasandinata, Neti Sumiati. (2014). Peran Pengelolaan Radio Komunitas dalam Mengembangkan Siaran Kearifan Lokal. Jurnal Penelitian Komunikasi Vol. 17 No.2, Desember 2014: 165-176

Ife, Jim \& Tesoriero, Frank. (2016). Community Development. Alternatif Pengembangan Masyarakat di Era Globalisasi. Jakarta: Pustaka Pelajar

Kridasaksana, Doddy., Junaidi M., dan Aryaputra, M Iftar. (2017). Tujuan Negara dalam Mengatur Frekuensi Radio Komunitas ditinjau dari Undang-Undang Nomor 32 tahun 2022 tentang Penyiaran (Studi Kasus Di wilayah Semarang). http://journals.usm.ac.id/index.php/jdsb/article/view/489

Manullang, M. (2008). Dasar-dasar Manajemen. Yogyakarta: Gajah Mada University Press

Maryani, Eni. (2011). Media dan Perubahan Sosial. Suara Perlawanan melalui Radio Komunitas. Bandung: Rosda

Masduki. (2005). Menjadi Broadcaster Profesional. Yogyakarta: PT. LKiS

Majdi, Udo Yamin Efendi. (2007). Quranic Quotient. Jakarta: Qultum Media

Morissan. 2008. Manajemen Media Penyiaran. Strategi Mengelola Radio dan Televisi. Jakarta: Kencana.

Mukhotib MD. (2015). Bagaimana Mendirikan Radio Komunitas. Yogyakarta: Combine Nasdian, Fredian Tonny. (2014). Pengembangan Masyarakat. Jakarta: Yayasan Pustaka Obor Indonesia

Oramahi, Hasan Asy'ari. (2012). Jurnalistik Radio. Kiat Menulis Berita Radio. Jakarta: Erlangga

Profil Radio Komunitas Dapur Remaja. Dokumentasi Radio

Sari, Rika Ratna. (2015). Tingkat Partisipasi Komunitas dalam Penyelenggaraan Radio Komunitas (Laporan Studi Pustaka). Bogor. Institut Pertanian Bogor

Warren. R. (1978). The Community in America. Third Edition. Chicago: Rand-McNally 
Yuliasari, Ika., dkk. (2015). Meretas Hambatan Komunikasi Perdesaan dengan Media Komunitas di Daerah Istimewa Yogyakarta. Jurnal Penelitian Pos dan Informatika JPPI Vol 5 No 2 (2015) 191 - 212 